\title{
ФОРСИРОВАННОЕ ПЕНИЕ БЕЗ ОПОРЫ ДЫХАНИЯ И ЕГО ПОСЛЕДСТВИЯ
}

\author{
С. В. Коротеева \\ (Московский гуманитарный университет)
}

Аннотация: В статье отмечается проблемы современного преподавания пения для детей и подростков. Как считает автор, овладеть правильно специальными навыками экстремального вокала с нуля, не умея хорошо контролировать свой «чистый» голос невозможно и опасно.

Ключевые слова: вокал; пение; эстрада; эстрадный вокал; форсированное пение

\section{FORCEFUL SINGING WITHOUT BREATH SUPPORT AND ITS CONSEQUENCE}

\author{
S. V. Koroteyeva \\ (Moscow University for the Humanities)
}

\begin{abstract}
The article explores the issues of teaching singing to children and teenagers. We argue that it is impossible to acquire and correctly use professional skills of extreme singing from scratch without learning how to control one's "clear" voice. Trying to do so may seriously harm one's singing voice.

Keywords: vocal; singing; pop music; vocal in pop music; forceful singing
\end{abstract}

Тенденция последнего времени в области эстрадного вокала - форсированное пение, искусство исполнения рiano - практически утеряно, мало кто владеет динамическими нюансами и техникой филировки звука. Последствия такого пения бывают весьма плачевны - начиная от устойчивых узлов на связках и последующего длительного лечения и заканчивая эффектом «старческой гортани». В связи с огромной популярностью классических и эстрадно-вокальных форм в нашей стране появилось огромное количество коммерческих конкурсов для певцов различных возрастных категорий, которые позволяют сделать вывод: возраст вокалистов в значительной степени помолодел!

Занятия вокалом с маленькими детьми и подростками стимулируются также значительным числом различных детских и юношеских телевизионных конкурсов. В стране увеличивается количество различных 
студий современного вокала, где занятия зачастую проводят неквалифицированные преподаватели, не имеющие необходимых знаний в детской и подростковой физиологии и психоразвитии. Репертуар тоже перестал быть детским, а дети, копируя вокал взрослых певцов, начинают кричать, не понимая, о чем поют. Однако искусство пения - это кропотливая, постепенная и последовательная работа не одного дня (Морозов, 2002; Щербинина, 2015). К сожалению очень часто этого не понимают и родители детей. Поддавшись эффектным слоганам и рекламе, они готовы в угоду своим амбициям выкладывать круглые суммы, лишь бы любимое чадо попало в телевизор. Многие популярные студии эстрадного вокала, не стесняясь, спекулируют своими возможностями и связями с миром шоу-бизнеса, обещая быстрый результат, как говорится «за ваши деньги любой каприз». Как отреагирует психика ребенка на радость большой победы или горечь поражения сложно предугадать.

Поднимая тему детского и подросткового пения, мы говорим о наших потенциальных первокурсниках, многие из которых приходят к нам с изломанной психикой и устойчиво-наработанными не правильными вокальными навыками.

Искусство пения - это совокупность теории и живого опыта, иными словами - «Вокальная школа». Экспериментально-теорети-ческие исследования, так или иначе, всегда оказывали влияние не только на теорию, но и на практику вокальной педагогики и, в конечном счете - исполнительства. В России история научного изучения вокала связана с деятельностью таких центров, как Академическая лаборатория Московской консерватории, лаборатория биоакустики им. Сеченова и вокальнометодическая лаборатория Института им. Гнесиных.

Но проблема в том, что на сегодняшний день литературы написанной и обоснованной с научной точки зрения или хотя бы, претендующей на научную новизну, чрезвычайно мало. Легендарная книга Л. Б. Дмитриева «Основы вокальной методики» была издана в 1968 г. (Дмитриева, 1968) и она до сих пор служит студентам основой для написания дипломных работ и рефератов, а также для понимания физиологических процессов, которые происходят во время пения. Но если вы заглянете в Интернет, то обязательно обнаружите огромное количество пособий и самоучителей для вокалистов, сайтов и страничек, отдельно взятых блогеров, которые активно консультируют интересующихся пением людей. Вот пообщаются на таких форумах начинающие вокалисты с «интернет кудесниками» и считают себя уже мастерами большой сцены. Я совершенно точно знаю, что студенты, особенно начальных курсов тоже увлекаются различными методиками и интернет форумами.

Справедливости ради, следует все же отметить, что встречаются в 
интернет-пространстве и толковые сайты, и интересные статьи. И задача студентов научиться отделять зерна от плевел. Если не научиться работать с информацией сейчас, потом, после окончания вуза, могут возникнуть ситуации, которые могут повлечь очень серьезные последствия. Хорошо (в смысле, конечно, плохо!!!) если выпускник, предположим, начинающий артист из-за плохо усвоенных знаний или не отработанных вокальных навыков навредит себе и будет вынужден долго лечить свой голосовой аппарат. Гораздо хуже, когда, не найдя применения «своим талантам» на большой сцене он захочет преподавать вокал. Вот тогда в группу риска попадают потенциальные ученики горе-педагога, чаще всего это дети.

Очень показателен один случай, который произошел у меня в Челябинске. Я консультировала детей из одной вокальной студии. На консультации также присутствовали родители. Одна девочка (11 лет) очень громко (практически надрывно), очень эмоционально и, конечно же, на английском языке, исполнила песню, а после исполнения я попыталась с ней поговорить - о чем песня, почему она решила ее спеть? В ответ вместо голоса услышала жуткий сип. Я спросила у мамы, всегда ли так разговаривает ребенок после пения? Ответ меня поразил. Мама спокойно, как о чем-то самом обыкновенном и ничего не значащем сообщила мне, что у девочки узлы на связках. Не микроузел, не узел, а узлы! Т. е. она о них знает, а ее ребенок все равно продолжает занятия пением, причем в довольно агрессивной, кричащей манере, активно принимает участие в вокальных конкурсах, усугубляя и без того непростую ситуацию. На вопрос о том, почему они до сих пор не у фониатра, мама слегка даже удивилась: «А зачем?» А у меня в свою очередь возникло два вопроса: почему преподаватель девочки не прекратил занятия, если диагноз уже известен, и почему не разъяснил родителям всю тяжесть последствий? Благо, мама оказалась разумной и по моему совету бегом отправилась к одному из лучших врачей города Москвы Л. Б. Рудину.

Одна из самых трудных проблем вокальной педагогики - это научить певца петь без опасного для голоса перенапряжения гортани и голосовых связок. Русская школа вокала формировалась под воздействием итальянской школы и от итальянской не отличалась. Но проблема в том, что итальянская школа до сих пор считается секретной, практически отсутствуют пособия на эту тему. Да и в самой Италии не принято говорить о приемах бельканто, поскольку это тайна, национальное достояние!

С каждым днем в нашей стране увеличивается количество преподавателей вокала, пропагандирующих сомнительные методики. Несколько лет назад на русский язык была переведена книга известного представителя шоу-бизнеса, американского педагога-вокалиста Сета Риггса «Как стать звездой», в которой он пропагандирует методику, суть которой сам 
автор обозначил как «пение в речевой позиции» (Риггс, 2000). В свое время эта книга наделала много шума, отголоски этого шума слышны до сих пор в возросшем количестве студий вокала, которые занимаются якобы по методике Сета Риггса. Однако многие педагоги крайне негативно отзываются об этой методике. И дело не только в «закостенелом академическом мышлении», судите сами, чего только стоит заявление, что дыхание во время пения - это расслабленный процесс. А на вопрос «Что Вы можете сказать о дыхании?» дает потрясающий ответ - «Важность дыхания во время пения довольно длительное время слишком преувеличивалась. Правильное дыхание является побочным продуктом правильной техники пения. Не следует специально заниматься дыханием». Не советует поднимать мягкое небо и изменять произношение слов, обещает, что усиление звука произойдет само по себе. По всему очевидно, что Сет Риггс пытается заменить классическую школу вокала на пение «в речевой манере». Однако не будем забывать, что классическая школа это результат труда талантливейших и умнейших педагогов, певцов и ученых многих стран.

Говоря о применении методики Сета Риггса, на сегодняшний день мы имеем курсы повышения квалификации, которые проводит Московский методкабинет. Одну из лекций для слушателей читала методист по эстрадно-джазовому вокалу Московского методкабинета, которая утверждает, что петь надо в речевой позиции, на плоском небе. Чувствуете, откуда ветер дует? Однако сама, по словам моей коллеги, которая посещала эти курсы, поет вполне объемно, т. е. на зевке. У педагога со стажем нашлись бы аргументы для возражений, но неопытных начинающих педагогов - это заявление из уст методиста может ввести в глубокое заблуждение и стать началом конца педагогической деятельности.

Все чаще я слышу от своих коллег и из других вузов в том числе, что многие первокурсники приходят с заявлением о том, что правильно дышать не обязательно, главное найти свои фишки и примочки. И просят быстрее научить их этим самым «фишкам» и «примочкам», не забывая при этом удивить педагога знанием специфической профессиональной терминологии. Так что же означает слово «примочка». Чаще всего этот термин используется музыкантами - гитаристами. Практически любой гитарист, достаточно серьезно относящийся к исполнительскому мастерству, мечтает стать «узнаваемым гитаристом», то есть тем музыкантом, которого можно легко узнать на слух по его игре. (О том же самом мечтают и начинающие певцы!) Важную роль в выполнении этой задачи играет уникальная манера игры, но не последнее место занимает и индивидуальный, неповторимый звук. В этой ситуации на передний план выходят различные электронные устройства обработки сигнала («примочки»), которые могут кардинально изменить звучание электрогитары. Но ни одна 
«примочка» в мире не поможет гитаристу стать узнаваемым, если он элементарно не владеет техникой игры на гитаре, иными словами не имеет школы. Это же самое утверждение справедливо и для вокала. Необходимо понимать, что освоение любых голосовых «фишек и примочек» включает в себя обязательное знание базы вокала и специальных навыков. В последнее время появился такой термин как - экстремальный вокал, который в свою очередь подразделяется на такие виды как: grunt, growl, scream (его разновидности: lowscream, inhalescream), pigsqueal, distortion и др.

Однако, повторюсь - овладеть правильно специальными навыками экстремального вокала с нуля, не умея хорошо контролировать свой «чистый» голос невозможно и опасно, так как это неминуемо приведет к тому, что человек не просто не сможет петь, но и рискует потерять свой разговорный голос. И последствия могут быть непоправимыми.

\section{СПИСОК ЛИТЕРАТУРЫ}

Дмитриева, Л. Б. (1968) Основы вокальной методики. М. : Музыка. 368 с.

Морозов, В. П. (2002) Искусство резонансного пения. Основы резонансной теории и техники. М. : Московская государственная консерватория им. П. И. Чайковского. 496 с.

Риггс, С. (2000) Как стать звездой. Полный учебный курс. M. : Guitar College. 104 c.

Щербинина, М. В. (2015) Искусство пения как фактор освоения личностью вокалиста художественно-эстетических ценностей культурного пространства // ФӘН-НАУКА. № 3 (42). С. 67-68.

Коротеева Светлана Викторовна - профессор кафедры культуры и искусства Московского гуманитарного университета, лауреат международных премий. Адрес: 111395, Россия, г. Москва, ул. Юности, д. 5. Тел.: +7 (499) 374-59-40. Эл. адрес: 3730014@mail.ru

Koroteyeva Svetlana Viktorovna, Professor, Department of Culture and Art, Moscow University for the Humanities, international award winner. Postal address: 5 Yunosti St., Moscow, Russian Federation 111395. Tel.: +7 (499) 37459-40. E-mail: 3730014@mail.ru 